\title{
当院におけるプレガバリン使用状況
}

\author{
小 河 賢 司* 古市 格* 村 田 雅 和* 井上 拓 馬* \\ 森口昇*田中尚 洋* 坂井達 弥*
}

\section{A Survey on Usage of Pregabalin at Our Institution}

\author{
Kenji Ogawa*, Itaru Furuichi*, Masakazu Murata*, Takuma Inoue*, \\ Noboru Moriguchi*, Naohiro Tanaka*, and Tatsuya Sakai*
}

【目的】疼痛を愁訴にした患者に対して，整形外科やペインクリニックでは，薬物療法やブロック注射な どにより保存的治療を行ってきた。そこに，新たな薬物療法の選択肢としてプレガバリンが加わった．今 回，その使用方法などを検討する事を目的として，当院における当薬郕の使用状況を調查した。【対象と 方法】 2010 年 6 月から 2011 年 3 月までに当院にてプレガバリンを処方された 121 例について，処方した 診療科・対象病名・効果・副作用について調査を行い，問題点を抽出した.【結果】麻酔科 $(57 \%)$ - 整形 外科（19\%）の順で処方を行っていた．整形外科関連の処方では春椎疾患に対するものが多かった．癌性 疼痛に対して処方されている例も見られた。約 50\% の症例で除痛効果が得られていた.【結語】比較的効 果のある薬剤ではあるが，合併症・併用薬なども含め今後も検討を要する。

Pregabalin is a novel drug under development for its analgesic, anxiolytic, anticonvulsant properties, and its interaction with alpha (2) delta-subunit of voltage-dependent $\mathrm{Ca}(2+)$ channels. As a new pain treatment option, we started use of pregabalin for patients with neuropathic pain, and conducted a survey on proper usage at our hospital. We investigated the department prescribing pregabalin, target disease, efficacy, and side effects in 121 patients on new prescriptions for pregabalin from June 2010 to March 2011. As a result, we found that anesthesiologists (57\%) prescribed it the most followed by orthopedic surgeons (19\%). It was most often prescribed to patients with postherpetic neuralgia, and patients with spinal disorders in orthopedic surgery. It was also relatively prescribed for patients with cancer pain. Effective pain relief was obtained in approximately $50 \%$ of all cases. Prescription was discontinued in $12 \%$ of the patients due to side effects. Pregabalin was also prescribed to $35 \%$ of the patients for offlabel use at our hospital. In conclusion, pregabalin is an effective drug for neurological pain, but because it has relatively many side effects, use of the PainDETECT and BS-POP diagnostic tools is recommended when prescribing it.

Key words : pregabalin（プレガバリン）， a survey of usage（使用状況調査）, pain assessment（疼痛評 価)

\section{は じめに}

整形外科やペインクリニックを行っている麻酔科で

は，日々主に疼痛を愁訴とした患者の診療を行ってい

る。これまでは，手術適応でない疾患や適応があっ ても手術を選択できない患者の疼痛に対して，消炎鎮 痛剂（Non-Steroidal Anti-Inflammatory Drugs，以下
NSAIDs）の調整・鎮痛補助薬や漢方薬の併用・各種 ブロックを用いて保存的治療を行ってきた。近年，才 ピオイドも慢性疼痛などへの処方が可能となり，治療 の選択肢が広がってきている。また本来の使用法とは 異なるが, Selective Serotonin Reuptake Inhibitors (SSRI)/Serotonin \& Norepinephrine Reuptake Inhibitors（SNRI）を慢性疼痛に併用したり，抗不整脈薬

\footnotetext{
* 国立病院機構㛸野医療センター整形外科 Department of Orthopaedic Surgery, National Hospital Organization Ureshino Medical Center, Saga, Japan
} 
(メキシレチン) や抗㽷攣薬（カルバマゼピン・ガバ ペンチン）は痺れや疼痛に対して併用したりすること は有効であり，これまでも一部の症例では使用されて いた。そのような中， 2010 年 6 月より末梢性神経障 害性疼痛に適応のあるプレガバリンが使用可能とな り，より多くの症例に新たな薬物療法の選択肢が加 わった ${ }^{577}$.

プレガバリンは，末梢神経のシナプス前細胞に存在 するカルシウムイオンチャネルの $\alpha 2 \delta$ サブユニット に結合し，興奮性神経伝達物質の放出を抑制すること で疼痛刺激伝達を抑制する。保険適応のある薬剂とし ては新しい作用機序により疼痛を抑制できることもあ り, 当院でも難治性疼痛患者に処方される機会が多く なっている。しかし，その効果に期待するあまり本来 適応の無い症例にも処方される可能性があり, 普及で はなく氾濫を招く危険性がある ${ }^{4)}$.

そこで，当院におけるプレガバリンの使用状況を把 握することで, 今後の疼痛治療において適切な処方を 行う参考とするため調査を行った.

\section{対象と方法}

2010 年 6 月～ 2011 年 3 月までに当院でプレガバリ ンの処方が開始された患者 121 例を対象とした。処方 時平均年齢は 66 歳 (19 89 歳), 男性 55 人·女性 66 人と性差はなかった。処方診療科・処方対象疾患とそ の効果（効果あり・やや効果あり・効果なし・副作用 にて中止・効果不明の 5 段階評価）について調査し た.

\section{結果}

処方診療科は, 麻酔科が $57 \%$ と最も多く, 次いで

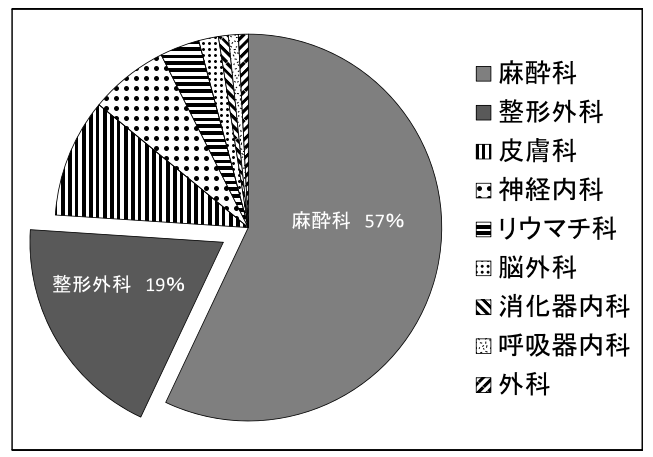

図 1 診療科別処方割合
表 1 処方対象疾患

\begin{tabular}{|c|c|}
\hline 帯状疮疹後神経痛 & 49 人 \\
\hline 脊椎疾患 & 22 人 \\
\hline 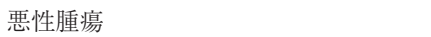 & 13 人 \\
\hline 末梢神経障害（絞扼性神経障害を含む） & 6 人 \\
\hline 複合性局所疼痛症候群（CRPS） & 5 人 \\
\hline 脳・觢䯣疾患 & 6 人 \\
\hline 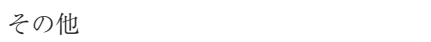 & 18 人 \\
\hline 低脊髄圧症候群 & \\
\hline $\begin{array}{l}\text { 凍偒 } \\
\text { 繊維筋痛症 }\end{array}$ & \\
\hline 術後難治性疼痛（創周囲痛）など & \\
\hline
\end{tabular}

整形外科が $19 \%$ と多かった（図 1). 入院処方 43 人, 外来処方 78 人で，神経内科以外では外来にて処方開 始されることが多かった，処方対象疾患は，带状疮疹 後神経痛が 49 人と最も多く, 脊椎疾患・悪性腫瘍な どに対しても処方されていた（表 1).

当院での明らかな適応疾患に対する処方は， $64.5 \%$ に過ぎず，腫瘍の神経浸潤に対して処方した症例など を含めると， $35.5 \%$ は本来の意味では適応外である 疾患への処方であった。

効果は，50\%（効果あり 38\%・やや効果あり 12\%） に効果を認めた。明らかな副作用により中止となった 症例は $12 \%$, 効果なし症例は $21 \%$, 効果不明症例は 17\%であった。

\section{症例}

症例 1.58 歳. 男性. (図 2)

腎がんの再発患者. 緩和ケアにて疼痛コントロール 目的で入退院を繰り返していた。骨盤への転移があり, 右坐骨神経痛が著明なためオピオイド持続点滴などを 受けていた。プレガバリン処方後は疼痛軽減し，持続 点滴をオピオイド貼付剤に変更可能となり，体動困難 が改善した。プレガバリン効果ありと判定した.

症例 2. 82 歳. 女性. (図 3)

腰部脊柱管狭窄症術後。一旦術後改善していた下肢 痛が再燃した症例で，明らかな再狭窄所見はなく，プ ロスタグランジン・NSAIDs・環系抗うつ薬にて経 過観察されていた。しかし, 徐々に疼痛増強したため, プレガバリンを追加処方したところ疼痛軽減し，三叉 神経痛にて内服していた抗痤攣薬も中止可能となっ た。プレガバリン効果ありと判定した. 

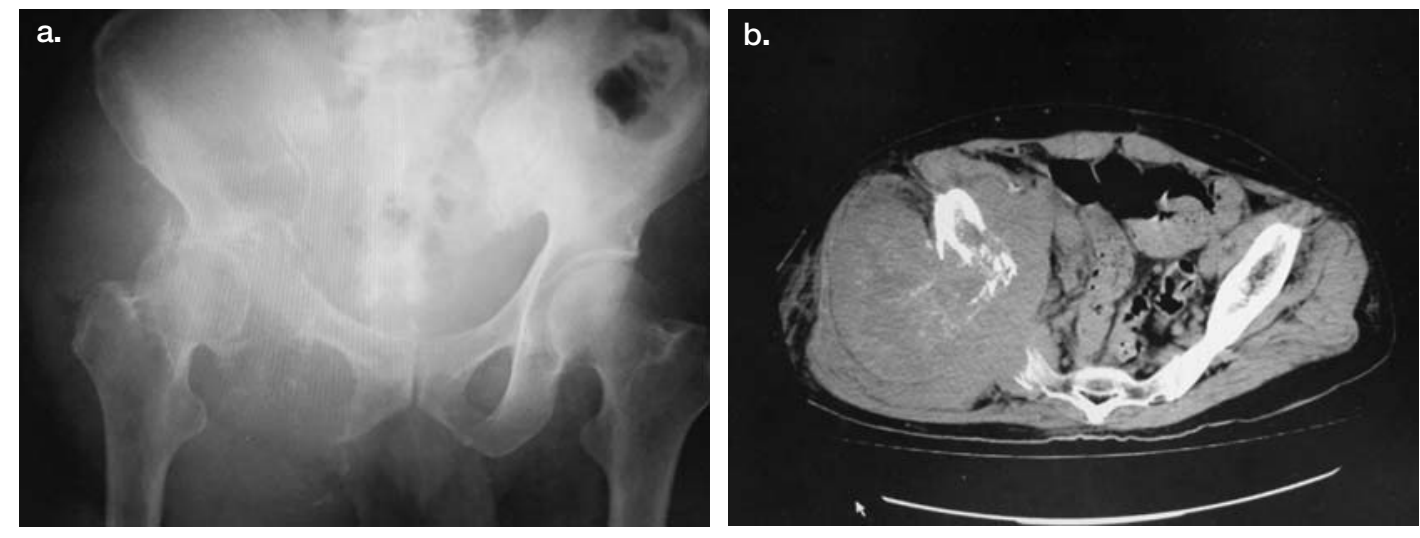

図 2 症例 1

(a) 骨盤正面単純 X 線写真 （b ）骨盤部 CT

右寛骨から恥・坐骨にかけて腎癌の転移を認め, 坐骨神経も巻き込まれている
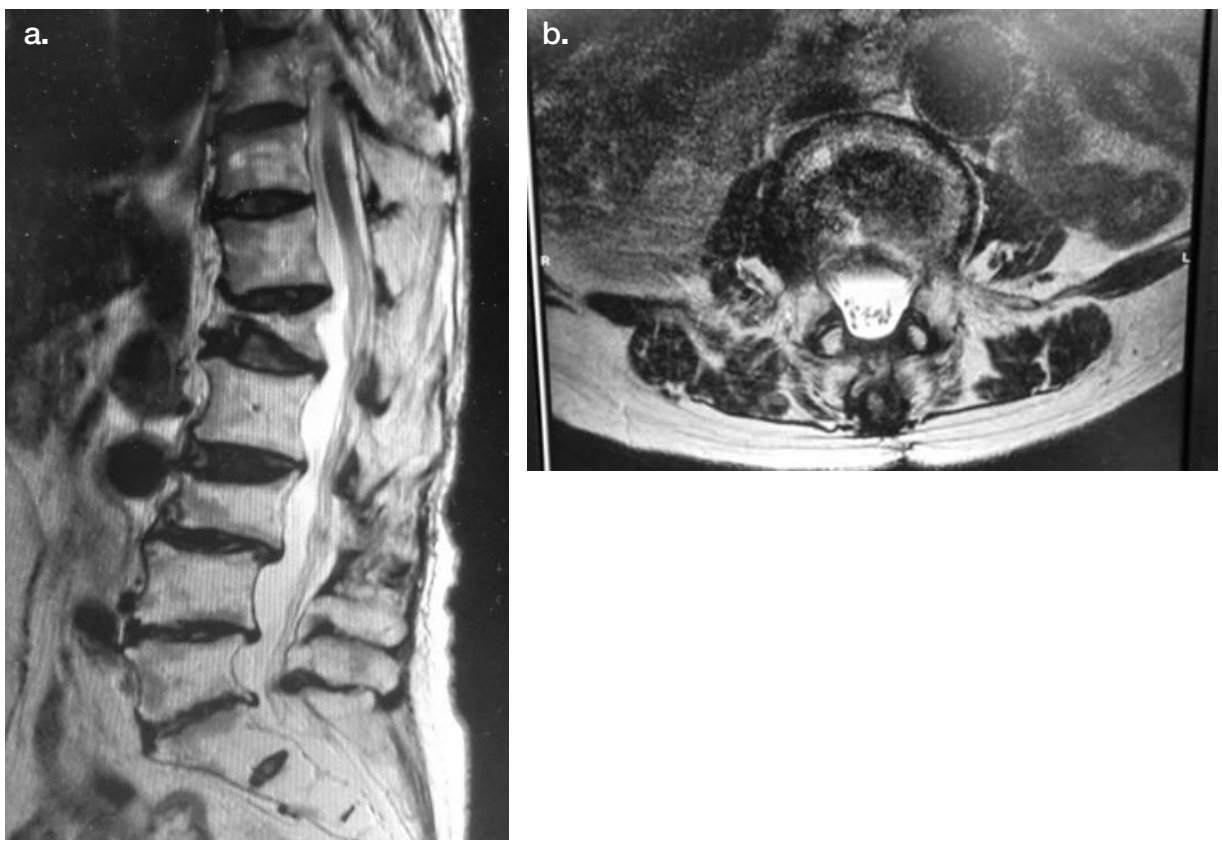

図 3 症例 2

L 3/4 開空術後 MRI （a）矢状面 （b）横断面 明らかな再狭窄部位は認めなかった

考察

プレガバリンは，当初帯状疱疹後神経痛と糖尿病性 末梢神経障害に伴う疼痛に対する治療薬として臨床試 験が行われた薬剤である。当院では, 糖尿病性末梢神
経障害には処方されてなかったが，帯状疱疹に対する 処方が多く，効果のある症例も多かった.

しかし，プレガバリンの適応症としては，上記に限 らず末梢性神経障害性疼痛となっており，すでに無作 為化比較試験が行われ有効性の認められている春髄神 
経根症 ${ }^{1)}$ その他の神経因性疼痛にも処方の範囲は広 がっている。

また近年，ガン性疼痛に対するリリカ処方の報告が 散見される ${ }^{3)}$. 当院でも 13 例に処方されていたが，効 果は様々で無効な症例もあるが, あくまでもオピオイ ドの補助的役割と考えれば，その併用効果は期待でき る印象がある.

本薬剤の適応・適応外を判定することは, 病状が末 梢神経障害に起因するものであるか否かを判定するこ とであり，非常に難しい問題を含んでいる.

今回の調査でも当院の適応外処方は $35.5 \%$ と少な くはないが，あくまでもカルテベースの retrospective な調査であり，処方時の症状が末梢神経に由来してい たかどうかの正確な判断は困難である。また，癌性疼 痛や中枢性神経障害性疼痛などでも有効であったとす る報告も散見されるようになってきている事や，その 他の適応外と考えられる症例の中にも神経障害性疼痛 の要素を含んでいるものがあることを考えると，これ ら適応外処方の全例が無効な処方とは言えない. しか しながら, 今回の調査で当院の「効果あり」症例が約 $50 \%$ というのは, 有効率が低いと言わざるを得ない. 適応外の可能性がある症例には，使用前にpainDE$\mathrm{TECT}^{2)}$ や BS-POP ${ }^{6)}$ といった診断ツールを用い，より 的確な診断を行う必要性がある. 今後, 当院内でも診 断ツールの普及に努めることで，「効果あり」症例の 割合を増やすことが出来るのではないかと思われる.

副作用についても注意が必要で, 承認時の国内外臨 床試験では検査值異常を含めると副作用発現率は約 $64 \%$ ，そのうち中等度以上の副作用が占める割合は約 $34 \%$ と高率である。当院でも副作用にて内服中止に 至った症例は $12 \%$ あり，眠気やふらつきなど軽度の ものから消化器症状・尿閉など重度のものまで認め た.目のちらつきなどの眼症状や四肢の浮腫を伴うこ ともあり, 処方した診療科だけでは対応が困難な事も
ある、そのため，院内の多くの科の医師にプレガバリ ンの副作用に対する知識を持ってもらい注意を呼びか ける事や，患者に対して十分な説明を行うことが副作 用対策として重要である.

\section{ま と め}

(1)当院におけるプレガバリン使用状況を調査した.

(2)神経因性疼痛には非常に有用な薬剤ではあるが，使 用に当たってはその副作用を十分説明でき，その対 応を考えておく必要がある。

(3)当院では薬効を期待した適応外処方が約 35\% あり, 今後診断ツールの普及などを院内で行っていく必要 がある。

\section{参 考 文 献}

1) Baron, R., et al. : The efficacy and safety of pregabalin in the treatment of neuropathic pain associated with chronic lumbosacral radiculopathy. Pain, 150:420-427, 2010.

2) Freynhagen, R., et al. : painDETECT : a new screening questionnaire to identify neuropathic components in patients with back pain. Curr. Med. Res. Opin., 22(10): 1911-1920, 2006.

3）井関雅子: 薬物療法 新しい鎮痛補助薬の有効性と今後 の展望 プレガバリンを中心に. ペインクリニック,27 (8) : 980-988, 2006.

4）松澤理恵ら：プレガバリンの院内処方状沉について 普 及あるいは氾濫? 。日本慢性疼痛学会・抄録集, 40 : 57, 2011 .

5）中村二郎：糖尿病性神経障害と高血圧. 血圧，18(2)： 38-42, 2011.

6）佐藤勝彦ら：脊椎・春髄疾患に対するリエゾン精神医学 的アプローチ（第 2 報）一整形外科患者に対する精神医 学的問題評価簡易質問票 (BS-POP) の作成. 臨整外, $35: 843-852,2000$.

7) 住谷昌彦ら : 薬物療法の問題点とその対策. 整・災外, 54 (9) : 1049-1058, 2011. 